\title{
Low molecular weight chitosan conjugated with folate for siRNA delivery in vitro: optimization studies
}

This article was published in the following Dove Press journal:

International Journal of Nanomedicine

22 November 2012

Number of times this article has been viewed

\author{
Julio C Fernandes' \\ Xingping Qiu ${ }^{2}$ \\ Francoise MWinnik ${ }^{2}$ \\ Mohamed Benderdour \\ Xiaoling Zhang ${ }^{3}$ \\ Kerong $\mathrm{Dai}^{3}$ \\ Qin Shi' \\ 'Orthopaedics Research Laboratory, \\ Research Centre, Sacré-Coeur \\ Hospital, ${ }^{2}$ Department of Physical \\ Chemistry and Polymer Science, \\ Faculty of Pharmacy, University \\ of Montreal, Montreal, Quebec, \\ Canada; ${ }^{3}$ Orthopaedic Cellular \\ and Molecular Biology Laboratories, \\ Institute of Health Sciences, Chinese \\ Academy of Sciences, Shanghai Jiao \\ Tong University School of Medicine, \\ Shanghai, China
}

Correspondence: Qin Shi

Orthopaedics Research Laboratory,

Research Centre, Sacré-Coeur Hospital, University of Montreal, 5400 Gouin Blvd

West, Montreal, Quebec,

Canada H4J IC5

Tel + I 5 I 3382172 ext 3043

Fax + I 5143382694

Email qin.shi@umontreal.ca

\begin{abstract}
The low transfection efficiency of chitosan is one of its drawbacks as a gene delivery carrier. Low molecular weight chitosan may help to form small-sized polymer-DNA or small interfering RNA (siRNA) complexes. Folate conjugation may improve gene transfection efficiency because of the promoted uptake of folate receptor-bearing cells. In the present study, chitosan was conjugated with folate and investigated for its efficacy as a delivery vector for siRNA in vitro. We demonstrate that the molecular weight of chitosan has a major influence on its biological and physicochemical properties, and very low molecular weight chitosan (below $10 \mathrm{kDa}$ ) has difficulty in forming stable complexes with siRNA. In this study, chitosan $25 \mathrm{kDa}$ and $50 \mathrm{kDa}$ completely absorbed siRNA and formed nanoparticles ( $\leq 220 \mathrm{~nm}$ ) at a chitosan to siRNA weight ratio of 50:1. The introduction of a folate ligand onto chitosan decreased nanoparticle toxicity. Compared with chitosan-siRNA, folate-chitosan-siRNA nanoparticles improved gene silencing transfection efficiency. Therefore, folate-chitosan shows potential as a viable candidate vector for safe and efficient siRNA delivery.
\end{abstract}

Keywords: nonviral vector, chitosan, gene delivery, folate-targeted, siRNA

\section{Introduction}

Gene transfer technology has developed at a rapid pace in recent years. Projected medical applications run the gene therapy gamut from hereditary to infectious diseases, cancers, and arthritis. Different vector systems have been tested in gene transfer studies for potential clinical use. Viral vectors, such as adenoviruses and retroviruses, are very effective in terms of transfection efficiency, but have limitations in vivo, in particular because of safety concerns. Nonviral gene transfer systems offer several potential advantages over virus vectors. They are noninfectious, relatively nonimmunogenic, have low acute toxicity, can accommodate large small interfering RNA (siRNA)/DNA plasmids, and can be produced on a large scale. Numerous nonviral gene transfer systems have been proposed, including cationic liposomes and polymers. ${ }^{1-3}$

The discovery of siRNAs has given new therapeutic vision to the treatment of incurable diseases and genetic disorders. RNA interference is a sequence-specific gene-silencing mechanism, leading to target protein downregulation in the cytoplasm of mammalian cells. ${ }^{4}$ Short, double-stranded RNAs are cleaved into $21-25$-base pair fragments by the RNAse III-like enzyme, Dicer, and incorporated into RNA-induced silencing complexes, thereby mediating targeted mRNA degradation. ${ }^{4}$ Chemically synthesized siRNAs and short-hairpin RNA expression plasmids, which are sequence-specific in targeting mRNAs, are common methods that mimic Dicer cleavage. ${ }^{5}$ However, siRNAs are susceptible to nuclease destruction and cannot 
penetrate the cell membrane because of their highly charged backbone. An effective delivery system, in which siRNA are incorporated in carriers, could protect and transport siRNA to the cytoplasm of target cells. ${ }^{1-3}$

Chitosan and its derivatives have attracted attention as favorable nonviral vectors involved in the delivery of plasmid DNA in the field of siRNA delivery in vitro ${ }^{6-9}$ and in vivo ${ }^{10}$ because of their low toxicity, high biocompatibility, and biodegradability. The main drawback of chitosan as a gene carrier is its typically low transfection efficiency. It has been demonstrated that transfection efficiency is closely related to the molecular weight of polymers. ${ }^{11}$ Chitosan (10-150 kDa), with a specific degree of deacetylation, allows maximum transgenic expression in vitro. ${ }^{12}$ Another strategy for improving transfection is to take advantage of folate uptake by cells to promote targeting and internalization, thereby enhancing transfection efficiency. Folate-mediated transfection has been shown to facilitate DNA internalization into cells via membrane receptors both in vitro and in vivo. ${ }^{13}$ Folate receptors are overexpressed on activated (but not resting) macrophages that cause or contribute to inflammatory diseases, such as rheumatoid arthritis. Malignant cells also found to overexpress folate receptors include ovarian cancer and other malignancies. ${ }^{14}$ Folate receptor distribution is largely restricted to malignant tissues, and folate receptors are now considered to be selective drug targets for the treatment of cancer and inflammatory diseases. ${ }^{15}$

In the present study, we labeled low molecular weight chitosans with folic acid (FA). The potential of folateconjugated chitosan as a carrier for siRNA delivery was then explored in vitro. The experimental data reveal that the functional group on folate increased the transfection efficiency of the chitosan-siRNA complex in HeLa and OV-3 cell lines, which are known to have high folate receptor expression.

\section{Materials and methods \\ Materials}

Chitosan (molecular weight $53.4 \mathrm{kDa}, 85 \%$ deacetylation) was purchased from Wako Chemicals USA Inc (Richmond, VA). Dulbecco's Modified Eagle's Medium, fetal bovine serum, $0.25 \%$ trypsin-ethylenediamine tetra-acetic acid (EDTA) solution, penicillin-streptomycin mixture, agarose, ethidium bromide, and Lipofectamine ${ }^{\circledR}$ reagent were sourced from Invitrogen Canada Inc (Burlington, ON). FA and other chemicals, if not otherwise stated, were obtained from Sigma-Aldrich Chemical Co, (St Louis, $\mathrm{MO}$ ). Sjogren syndrome antigen (SSB, GenBank accession number NM_009278)-targeted siRNA was provided by
Merck and Co, Inc, (West Point, PA). SSB siRNA was selected as a validated siRNA to evaluate our delivery strategies.

\section{Low molecular weight chitosan and folate-chitosan synthesis}

Chitosan of different low molecular weights $(2,5,10$, and $25 \mathrm{kDa}$ ) was prepared as described elsewhere. ${ }^{16}$ Chitosan of different molecular weights was further deacetylated by treatment with concentrated $\mathrm{NaOH}$ solution $(50 \%)$ to achieve approximately $96 \%$ deacetylation, according to a previously reported procedure. ${ }^{17}$ Folate-chitosan conjugation with poly(ethylene glycol) (PEG) was done according to the method reported by Cho et al, ${ }^{18}$ with some modifications. Experimental details are given in the Supplementary information section.

\section{Instrumentation}

${ }^{1} \mathrm{H}-\mathrm{NMR}$ spectra were recorded using a Bruker ARX-400 $400 \mathrm{MHz}$ spectrometer. $\mathrm{A} \mathrm{DCl} / \mathrm{D}_{2} \mathrm{O}(1: 100, \mathrm{v} / \mathrm{v})$ mixture served as the solvent for the chitosan spectra. Ultraviolet-visible spectra were measured using a Hewlett Packard 8452A photodiode array spectrometer. The folate incorporation level was $1.1 \%$ with respect to chitosan amino groups, as determined by ultraviolet spectroscopy using FA as the standard. The extinction coefficient $\left(\lambda_{363 \mathrm{~nm}}\right)$ of folate was ascertained to be $6165 \mathrm{M}^{-1} \mathrm{~cm}^{-1}$ in phosphate buffer $0.1 \mathrm{M}$ (pH 7.4).

\section{Chitosan and folate-chitosan-siRNA complexes}

Chitosan and folate-chitosan of different molecular weights were dissolved overnight with low heating (below $45^{\circ} \mathrm{C}$ ) in $20 \mathrm{mM}$ acetic acid solution, adjusted to final concentrations of 1,5 , or $10 \mathrm{mg} / \mathrm{mL}$ in $5 \mathrm{mM}$ acetic acetate buffer ( $\mathrm{pH} 5.5$ ) and then passed through a $0.45 \mu \mathrm{m}$ filter.

Chitosan-siRNA or folate-chitosan-siRNA complexes at weight ratios of 10:1, 50:1, or 100:1 were generated at room temperature by adding $50 \mu \mathrm{g}(50 \mu \mathrm{L}$ of $1 \mathrm{mg} / \mathrm{mL}), 250 \mu \mathrm{g}$ $(50 \mu \mathrm{L}$ of $5 \mathrm{mg} / \mathrm{mL})$, or $500 \mu \mathrm{g}(50 \mu \mathrm{L}$ of $10 \mathrm{mg} / \mathrm{mL})$ of chitosan or folate-chitosan in $5 \mathrm{mM}$ acetate buffer (pH 5.5) to $5 \mu \mathrm{g}$ of siRNA in $50 \mu \mathrm{L}$ of $4.3 \mathrm{mM}$ sodium sulfite buffer ( $\mathrm{pH} 5.5$ ). The solution was vortexed immediately at maximum speed for one minute. The complex solutions produced were used for the following experiments without further modification.

\section{Particle size}

Particle size was measured by Zetasizer Nano ZS90 (Malvern Instruments Ltd, Worcestershire, UK). Next, $100 \mu \mathrm{L}$ of 
chitosan-siRNA or folate-chitosan-siRNA complexes at weight ratios of 10:1, 50:1, or 100:1 were obtained as indicated earlier. The final volume of $100 \mu \mathrm{L}$ was processed with disposable, low-volume polystyrene $(100 \mu \mathrm{L})$ cuvettes. Particle size was measured in triplicate.

\section{Zeta potential}

The zeta potential of chitosan-siRNA or folate-chitosan-siRNA complexes was quantified by Zetasizer Nano ZS90 based on the principle of phase analysis light scattering, and $100 \mu \mathrm{L}$ of chitosan-siRNA or folate-chitosan-siRNA complexes at weight ratios of $10: 1,50: 1$, or 100:1 were generated as indicated earlier. The solution was then diluted to $1 \mathrm{~mL}$ with mixed buffer (half volume of $5 \mathrm{mM}$ acetate buffer and half volume of $4.3 \mathrm{mM}$ sodium sulfite buffer). Measurements were repeated three times in disposable zeta potential capillary cells.

\section{siRNA integrity after synthesis}

siRNA binding to chitosan or folate-chitosan was measured by $2 \%$ agarose gel electrophoresis in Tris-borate EDTA buffer (4.45 mM Tris-base, $1 \mathrm{mM}$ sodium EDTA, $4.45 \mathrm{mM}$ boric acid) at $\mathrm{pH}$ 8.0. Chitosan or folate-chitosan-siRNA complexes were loaded $(20 \mu \mathrm{L}$ of sample containing $0.5 \mu \mathrm{g}$ of siRNA and $3.5 \mu \mathrm{L}$ of $50 \%$ glycol) on the gel, and electrophoresed at $150 \mathrm{~V}$ for 30 minutes. The gel was stained with ethidium bromide $(0.5 \mu \mathrm{g} / \mathrm{mL})$ and photographed in a MultiImage ${ }^{\mathrm{TM}}$ light cabinet (Alpha Innotech Corporation, San Leandro, CA).

\section{Cell culture and transfection protocol}

HeLa cervical carcinoma (folate receptor-positive), OV-3 ovarian carcinoma (folate receptor-positive), and MG-63 osteosarcoma (folate receptor-negative) cells were obtained from the American Type Culture Collection (Rockville, MD). They were grown in Dulbecco's Modified Eagle's Medium, Ham's F12/Dulbecco's Modified Eagle's Medium, and RPMI 1640, respectively. The cells were cultured in an atmosphere of $5 \% \mathrm{CO}_{2}$ and $95 \% \mathrm{O}_{2}$ at $37^{\circ} \mathrm{C}$. They were seeded, 24 hours prior to transfection, in 24-well plates at a density of 50,000 cells/well in $1 \mathrm{~mL}$ of their usual culture medium supplemented with $10 \%$ fetal bovine serum and $1 \%$ penicillin-streptomycin. On the day of transfection, the culture medium was replaced by $500 \mu \mathrm{L}$ of complete medium containing free siRNA, chitosan-siRNA, or folate-chitosan complexes and siRNA equivalent to $5 \mu \mathrm{g}$. After 6 hours of incubation, the cells were incubated in $1 \mathrm{~mL}$ of complete medium until 60 hours after transfection. Chitosan or folate-chitosan nanoparticle at weight ratios of 50:1 were incubated for 30 minutes at room temperature and tested without further modification.

\section{Cell viability}

The cells were seeded and transfected with free siRNA, chitosan-siRNA, or folate-chitosan-siRNA complexes, followed by 24 hours of incubation. Cell viability was then evaluated by 3-[4, 5-dimethylthiazol-2-yl]-2,5-diphenyltetrazolium bromide (MTT) colorimetric assay based on MTT reduction by mitochondria in viable cells to water-insoluble formazan. Absorbance was measured at $570 \mathrm{~nm}$ using an EL800 universal microplate reader (Molecular Devices Corporation, Menlo Park, CA). Cell viability was expressed as the percentage of absorbance relative to the controls, which comprised cells not exposed to chitosan materials. Experiments were performed in triplicate. $\mathrm{IC}_{50}$, representing the concentration at which $50 \%$ of cell growth is inhibited, was calculated and expressed as the mean \pm standard error of the mean.

\section{Evaluation of transfection efficiency}

Total RNA was extracted from cells using TRIzol reagent (Invitrogen Canada Inc) according to the manufacturer's specifications. RNA was quantified using a RiboGreen RNA quantitation kit (Molecular Probes, Eugene, OR). For real-time reverse transcription-polymerase chain reaction (RT-PCR) analysis, $1 \mu \mathrm{g}$ of total RNA was reversetranscripted with a reverse transcription kit (Qiagen Inc, Mississauga, ON), as detailed in the manufacturer's guidelines. One-fifth of the reverse transcriptase reaction was analyzed by real-time quantitative PCR. The following primers were used: SSB, forward $5^{\prime}$-CCA AAA TCT GTC ATC AAA TTG AGT ATT-3', reverse 5'-CCA GCC TTC ATC CAG TTT TAT CT-3 ${ }^{\prime} ;{ }^{19} \beta$-actin housekeeping gene, forward 5'-AGC CTC GCC TTT GCC GA-3', reverse 5'-CTG GTG CCT GGG GCG-3' ${ }^{\prime}{ }^{20}$ SSB mRNA expression in cultured cells was expressed as the fold change relative to control conditions (nonstimulated cells), according to the $\Delta \Delta \mathrm{C}_{\mathrm{T}}$ method detailed in the guidelines supplied by the manufacturer (Stratagene, La Jolla, CA). $\Delta \mathrm{C}_{\mathrm{T}}$ values were first calculated by subtracting $\mathrm{C}_{\mathrm{T}}$ values for the $\beta$-actin housekeeping gene from each sample. $\Delta \Delta \mathrm{C}_{\mathrm{T}}$ values were then computed by subtracting $\Delta \mathrm{C}_{\mathrm{T}}$ values of the controls from the $\Delta \mathrm{C}_{\mathrm{T}}$ values of each treatment. Fold changes compared with the controls were then determined by raising 2 to the power of $\Delta \Delta \mathrm{C}_{\mathrm{T}}$. Each PCR was performed in triplicate on two separate occasions in at least three independent experiments. 


\section{FA competition study}

Cells were cultured under the same conditions as for the transfection tests. A $1 \mathrm{mg} / \mathrm{mL}$ FA solution was prepared. On the day of transfection, the culture medium was replaced by $500 \mu \mathrm{L}$ of complete medium containing free siRNA, chitosansiRNA, or folate-chitosan nanoparticles (the amount of siRNA in each well was $5 \mu \mathrm{g}$ ) with or without $20 \mu \mathrm{g}$ free FA. The cells were subsequently incubated at $37^{\circ} \mathrm{C}$ with these solutions for 4 hours in the presence of $5 \% \mathrm{CO}_{2}$ and with fresh medium for another 48 hours. Transfection efficiency was assessed as described earlier in the RT-PCR assay section.

\section{Statistical analysis}

The data are expressed as the mean \pm standard error of the mean of at least three independent experiments. All statistics were generated by Prism software (GraphPad Software, San Diego, CA). Statistical significance was analyzed using the unpaired Student's $t$-test. $P<0.05$ was considered to be statistically significant.

\section{Results}

\section{Characterization of chitosan-siRNA complexes}

The particle size and surface charge of different molecular weight $(2,5,10,25$, and $50 \mathrm{kDa})$ chitosan-siRNA complexes was measured (Figure 1). The degree of siRNA binding to chitosan was estimated by $2 \%$ agarose gel electrophoresis (Figure 2). The size of the particle complexes was directly proportional to the chitosan to siRNA weight ratio and molecular weight of chitosan. When the weight ratio or molecular weight increased, the size was amplified. The $2 \mathrm{kDa}$ chitosan-siRNA was unstable (Figure 1A). At a chitosan to siRNA weight ratio of $10: 1$, the $2 \mathrm{kDa}$ chitosan-siRNA complexes were larger in size $(606.4 \pm 5.8 \mathrm{~nm}$, Figure 1A), and their zeta potential indicated a negative charge $(-4.05 \pm 0.55 \mathrm{mV}$, Figure 1B). The $2 \mathrm{kDa}$ chitosan did not bind siRNA completely at any weight ratio (lane 3 in Figure 2A-C), indicating a weak interaction between siRNA and chitosan at the low molecular weight of $2 \mathrm{kDa}$. The positive surface charge of other chitosan-siRNA complexes ranged from $12.4 \mathrm{mV}$ to $17.8 \mathrm{mV}$ (Figure 1B). Polydispersity indexes were between 0.22 and 0.41 (Figure 1C).

For chitosan-siRNA complexes $(5,10,25$ and $50 \mathrm{kDa})$ at a chitosan to siRNA weight ratio of 10:1, the migration behavior was virtually the same as that of naked siRNA (Figure 2A), indicating that this weight ratio is unsuitable for protecting siRNA. At a chitosan to siRNA weight ratio of $50: 1$, the particle size varied between 161.1 and $216.1 \mathrm{~nm}$ (Figure 1A).
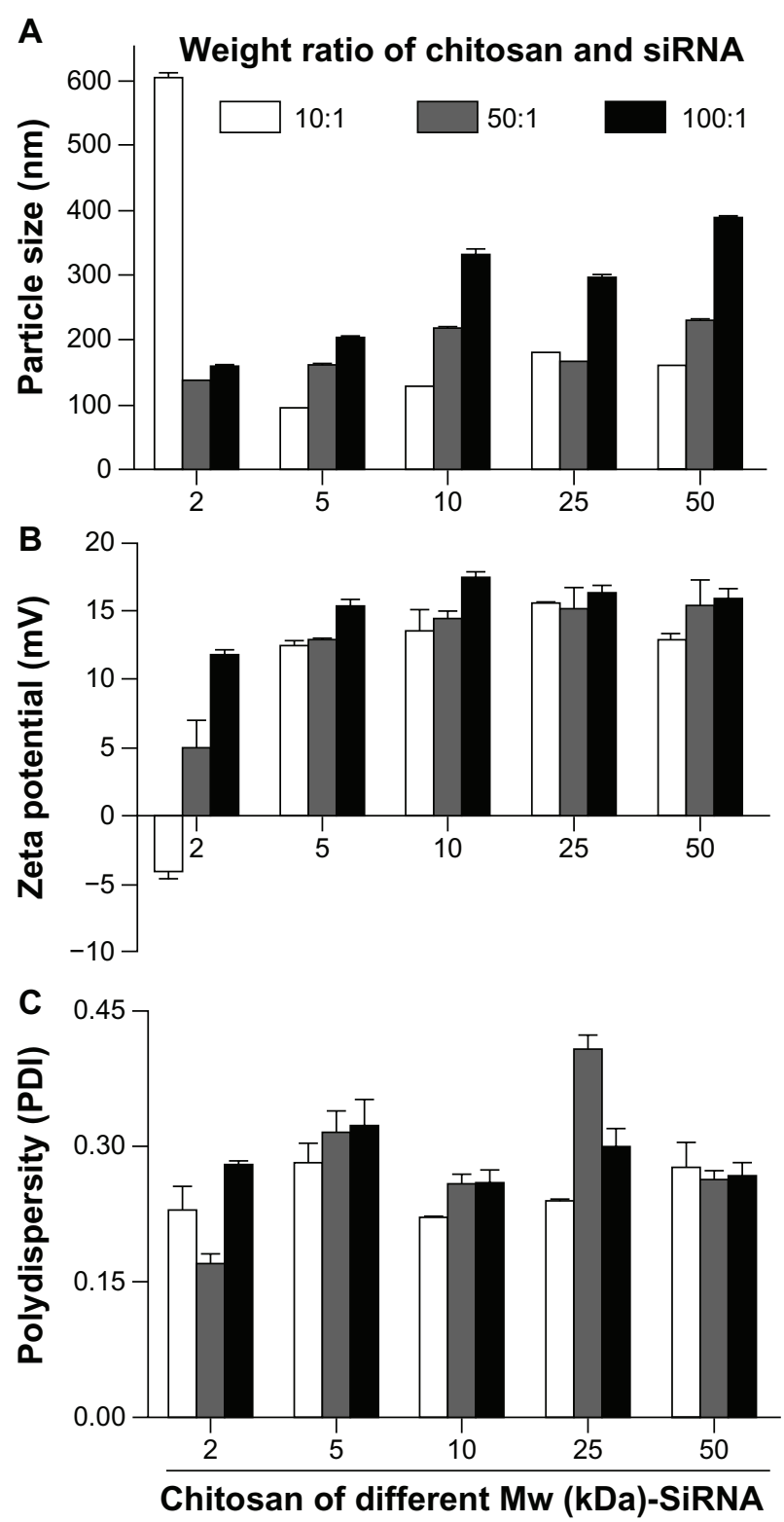

Figure I Characterization of chitosan-siRNA complexes. Size (nm) (A), zeta potential $(\mathrm{mV})(\mathbf{B})$, and PDI (C) of chitosan-siRNA complexes.

Note: The chitosan-siRNA complexes were at a chitosan to siRNA Sjogren syndrome antigen weight ratio of 10:1, 50:1, and 100:I, respectively.

Abbreviations: PDI, polydispersity index; MW, molecular weight; siRNA, small interfering RNA.

At a 100:1 weight ratio, the particle size increased with the molecular weight of chitosan (between 201.5 and $338.5 \mathrm{~nm}$, Figure 1A). However, only siRNA binding to $25 \mathrm{kDa}$ or $50 \mathrm{kDa}$ chitosan at a weight ratio of 50:1 could be observed with one peak of size distribution (results not reported).

\section{Cytotoxicity of chitosan and chitosan- siRNA complexes}

The cytotoxicity of the chitosan samples was examined by MTT assay using HeLa cells (Figure 3A). The dependence of 


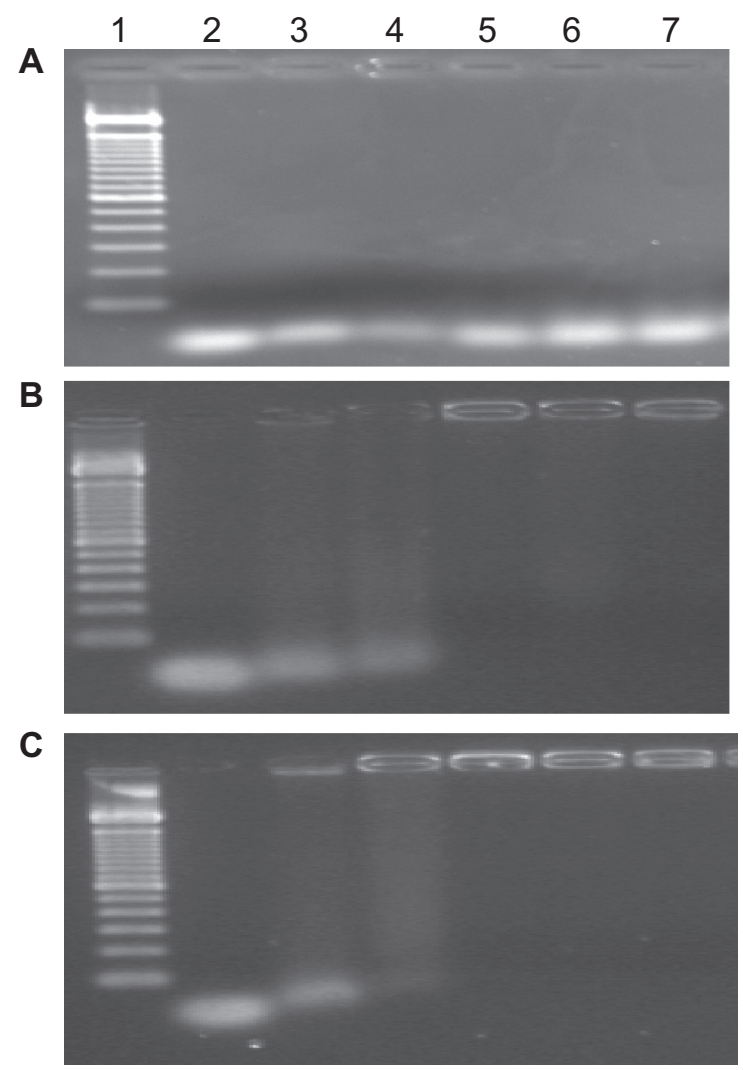

Figure 2 Electrophoresis analysis on $2 \%$ agarose gel. Effect of molecular weight of chitosan on siRNA binding efficacy at various chitosan to siRNA Sjogren syndrome antigen weight ratios of (A) I0:I, (B) 50:I, and (C) I00:I.

Notes: Lane I, ladder 100 base pairs; lane 2, free siRNA (0.5 $\mu \mathrm{g} /$ lane); lane 3, $2 \mathrm{kDa}$ chitosan-siRNA complexes; lane 4, $5 \mathrm{kDa}$ chitosan-siRNA complexes; lane 5 , $10 \mathrm{kDa}$ chitosan-siRNA complexes; lane 6, 25 kDa chitosan-siRNA complexes; lane 7, $50 \mathrm{kDa}$ chitosan-siRNA complexes.

Abbreviation: siRNA, small interfering RNA.

cell viability on polymer composition after 24 hours of cell incubation with different concentrations ( 0 to $3 \mathrm{mg} / \mathrm{mL}$ ) of the polymer solution is shown in Figure $3 \mathrm{~A}$. $\mathrm{IC}_{50}$ values for chitosan of different molecular weights were $0.21 \mathrm{mg} / \mathrm{mL}$ ( $2 \mathrm{kDa}$ chitosan), $0.42 \mathrm{mg} / \mathrm{mL}$ ( $5 \mathrm{kDa}$ chitosan), $2.2 \mathrm{mg} / \mathrm{mL}$ (10 kDa chitosan), $2.2 \mathrm{mg} / \mathrm{mL}$ ( $25 \mathrm{kDa}$ chitosan), and $1.5 \mathrm{mg} / \mathrm{mL}$ (50 kDa chitosan).

To investigate the cytotoxicity of the chitosan-siRNA complexes, cell viability was also examined by MTT assay after 24 hours of incubation (Figure 3B). Cells not treated with chitosan-siRNA complexes were considered as controls, with cell viability of $100 \%$. Figure 3B shows the effects of molecular weight of chitosan and the chitosan to siRNA weight ratio on cell viability. The results show at least $70 \%$ average cell viability for chitosan-siRNA complexes formulated with 10,25, or $50 \mathrm{kDa}$ chitosan at various weight ratios of 10:1, 50:1, or 100:1 (containing $5 \mu \mathrm{g}$ of siRNA). The amount of viable cells decreased slightly upon contact with free siRNA ( $5 \mu \mathrm{g} /$ well in 24 -well plates, $65.9 \%$ ) in
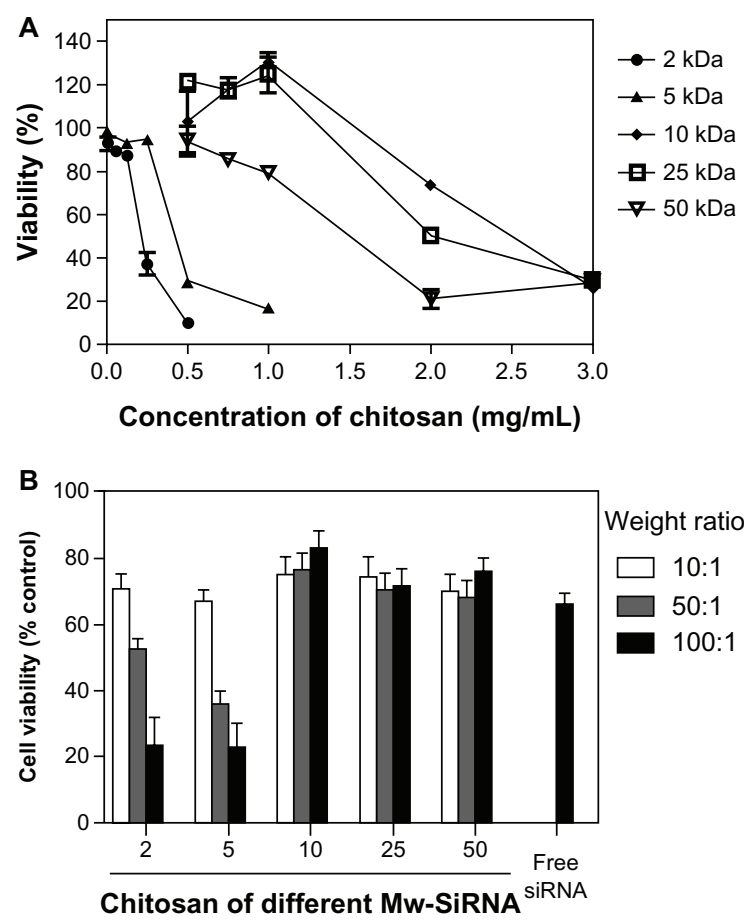

Figure 3 (A) In vitro cytotoxicity of the chitosans (polymer alone) of different molecular weights on HeLa cells as measured by MTT assay. (B) In vitro cytotoxicity of chitosan-siRNA complexes.

Notes: The chitosan-siRNA complexes were at a chitosan to siRNA Sjogren syndrome antigen weight ratio of $10: 1,50: I$, and I00:I, respectively.

Abbreviations: MW, molecular weight; siRNA, small interfering RNA.

comparison with untreated cells. It was also observed that $5 \mu \mathrm{g}$ of siRNA-Lipofectamine 2000 dramatically reduced cellular viability to below $40 \%$ (results not included). Viability declined significantly when the cells were incubated with $2 \mathrm{kDa}$ or $5 \mathrm{kDa}$ chitosan-siRNA at weight ratios of $50: 1(52.7 \%$ and $36.2 \%$ for $2 \mathrm{kDa}$ and $5 \mathrm{kDa}$ chitosan, respectively) and 100:1 (23.3\% and $22.8 \%$ for $2 \mathrm{kDa}$ and $5 \mathrm{kDa}$ chitosan, respectively).

\section{Synthesis and characterization of folate-chitosan-siRNA complexes}

The feasibility of folate-mediated chitosan targeting was investigated after coupling of folate with chitosan using PEG as a spacer. Based on the size and electrophoretic behavior of different molecular weight $(2,5,10,25$, and $50 \mathrm{kDa})$ chitosansiRNA complexes, only $25 \mathrm{kDa}$ and $50 \mathrm{kDa}$ molecular weight chitosan was conjugated with folate. The folate content of chitosan-PEG-folate was assessed by ultraviolet spectroscopy and found to be $1.1 \mathrm{~mol} \%$ for $50 \mathrm{kDa}$ chitosan-PEG-folate and $0.9 \mathrm{~mol} \%$ for $25 \mathrm{kDa}$ chitosan-PEG-folate with respect to chitosan glucosamine units, which corresponds to the fact that there are four and 1.3 folate molecules on each of the $50 \mathrm{kDa}$ chitosan-PEG-folate and $25 \mathrm{kDa}$ chitosan-PEG-folate 
chains, respectively (Figure 4A). We selected chitosan-siRNA and FA-chitosan-siRNA complexes at a weight ratio of 50:1. The ability of $25 \mathrm{kDa}$ or $50 \mathrm{kDa}$ folate-chitosan to interact with siRNA was investigated by agarose gel electrophoresis (Figure 4B). Complete siRNA binding to $25 \mathrm{kDa}$ or $50 \mathrm{kDa}$ chitosan and folate-chitosan vectors was observed (Figure 4B).

Introduction of the folate ligand onto chitosan decreased the size of the complex $(258.0 \pm 6.6 \mathrm{~nm}$ versus $143.3 \pm 0.7 \mathrm{~nm}$ for $25 \mathrm{kDa}$ chitosan-siRNA and
folate-chitosan-siRNA, respectively). The $50 \mathrm{kDa}$ chitosansiRNA complex sizes decreased from $207.7 \pm 2.6 \mathrm{~nm}$ to $120.5 \pm 1.9 \mathrm{~nm}$ in comparison with $50 \mathrm{kDa}$ chitosan-siRNA and folate-chitosan-siRNA, respectively. The nanoparticles remained stable in size for at least 24 hours (Figure 4C). Their zeta potential increased slightly within 24 hours, ranging from $11.02 \pm 0.59 \mathrm{mV}$ to $14.33 \pm 0.80 \mathrm{mV}$ (one hour after complex formation) and from $13.87 \pm 0.69 \mathrm{mV}$ to $19.27 \pm 0.56 \mathrm{mV}$ (24 hours after complex formation), respectively (Figure 4D).
A

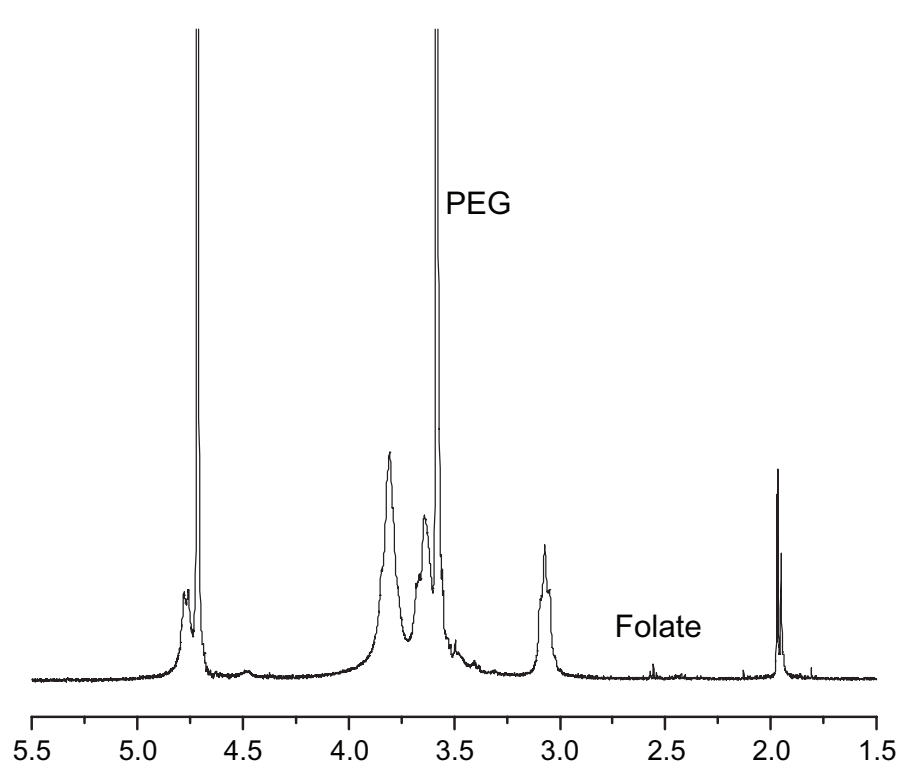

B

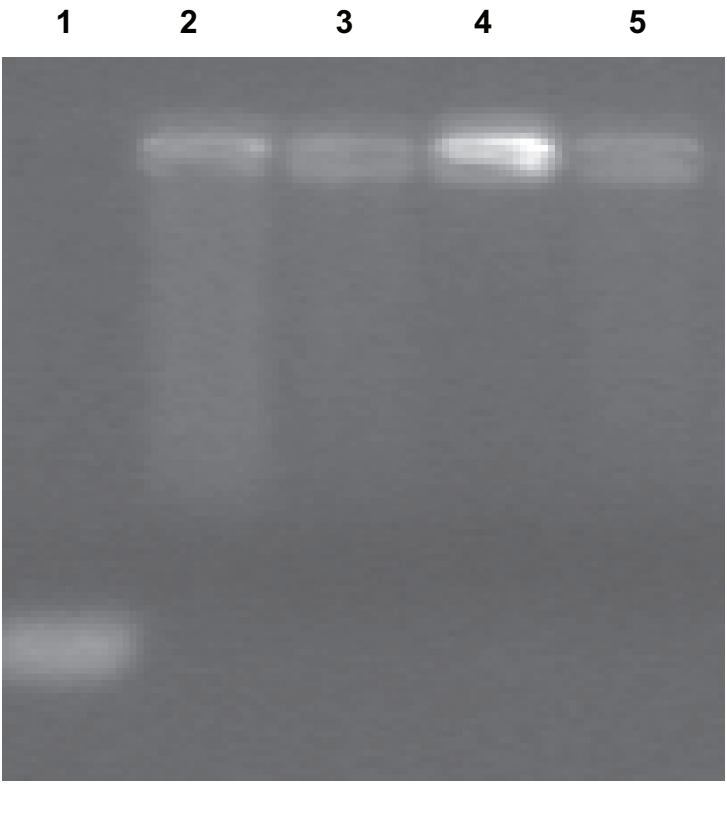

C
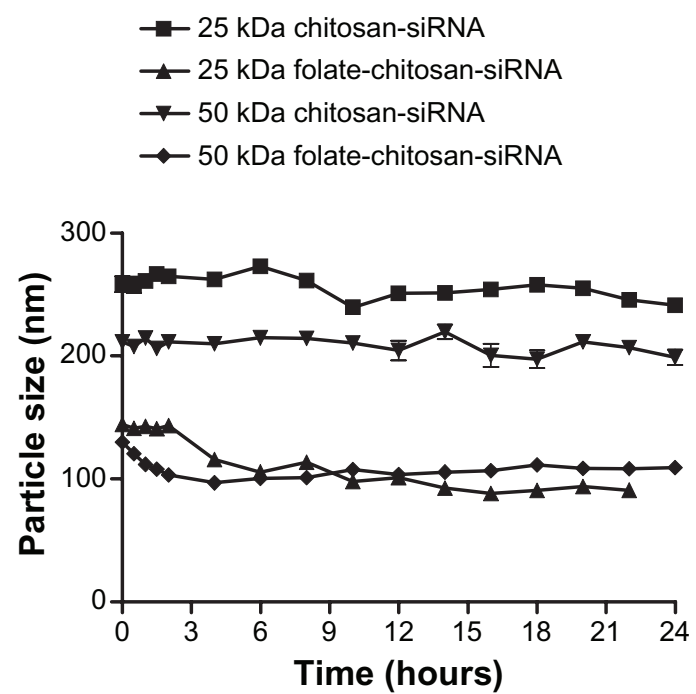

D
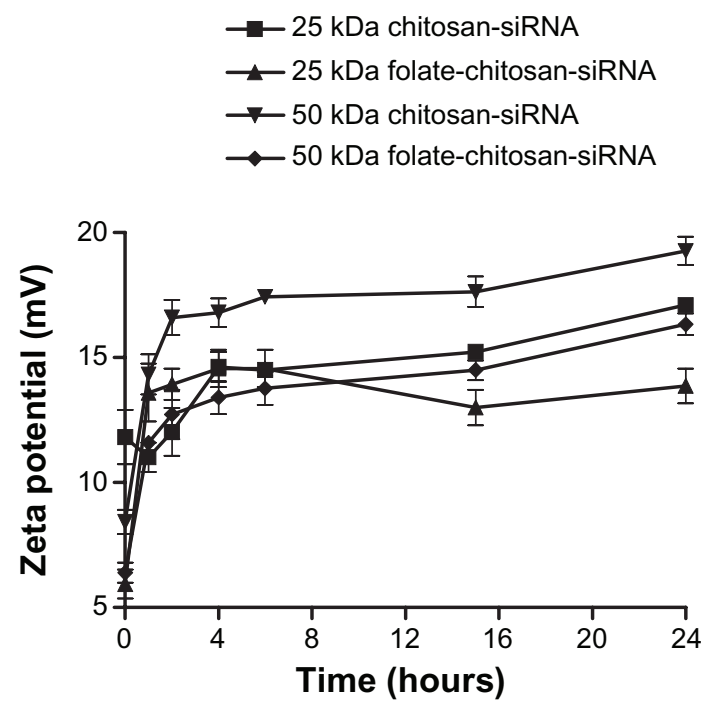

Figure 4 (A) 'H NMR spectrum of folate-chitosan. Solvent $D C l / D_{2} \mathrm{O}(\mathrm{I}: 100)$. (B) Electrophoresis analysis of chitosan or folate-chitosan/siRNA complexes at a weight ratio of $50:$ I on $2 \%$ agarose gel. Lane I, free siRNA Sjogren syndrome antigen $(0.5 \mu \mathrm{g} /$ lane); lane $2,25 \mathrm{kDa}$ chitosan-siRNA; lane 3 , $25 \mathrm{kDa}$ folate-chitosan-siRNA; lane 4 , $50 \mathrm{kDa}$ chitosan-siRNA; lane 5, $50 \mathrm{kDa}$ folate-chitosan-siRNA. (C) Time course of nanoparticle size (nM). (D) Time course of zeta potential (mV).

Abbreviations: PEG, poly(ethylene glycol); siRNA, small interfering RNA. 


\section{In vitro cytotoxicity of folate-chitosan- siRNA nanoparticles}

Cell viability was quantified by MTT assay after 24 hours of incubation with chitosan-siRNA or folate-chitosan complexes. Folate receptor-positive (HeLa and OV-3) and folate receptor-negative (MG-63) cells were tested. As shown in Figure $5 \mathrm{~A}$, over $50 \%$ of average HeLa cell viability was noted for free siRNA-treated cells in comparison with nontreated cells (considered as 100\%). Cell viability with chitosan $(25 \mathrm{kDa}$ or $50 \mathrm{kDa})$-siRNA complexes was not significantly different from that of free siRNA-treated cells, ie, 54\%-65\%. Compared with free SSB siRNA and chitosan-SSB siRNA, folate-chitosan-SSB siRNA was less cytotoxic and assigned more than $68 \%$ viability, which was significantly different from chitosan-SSB siRNA-treated cells $(P<0.01$ for $25 \mathrm{kDa}$ polymer-siRNA and $P<0.05$ for $50 \mathrm{kDa}$ polymer-siRNA, respectively). An average cell viability of $65 \%$ with free siRNA was observed in OV-3 cells (Figure 5B), with an average viability of over $87 \%$ for OV-3 cells treated with $25 \mathrm{kDa}$ chitosan-siRNA complexes, which increased slightly to $89 \%$ for $25 \mathrm{kDa}$ folate-chitosan-siRNA-treated cells. We noted that $50 \mathrm{kDa}$ chitosan and folate-chitosan-siRNA complexes were likely to decrease the viability of OV-3 cells $(64 \%-69 \%)$, but no significant viability difference in OV-3 cells was apparent between $25 \mathrm{kDa}$ chitosan-siRNA and folate-chitosan-siRNA or between $50 \mathrm{kDa}$ chitosan-siRNA and folate-chitosansiRNA. Average MG-63 cell viability was over $85 \%$ with free siRNA-chitosan and folate-chitosan-siRNA complexes at various polymer and siRNA weight ratios. However, there was no significant difference in viability between siRNA-chitosan and folate-chitosan-siRNA complexes (Figure 5C).

\section{In vitro gene silencing of folate-chitosan- siRNA nanoparticles}

To investigate the gene silencing efficiency of various chitosan and folate-chitosan-siRNA systems, HeLa and OV-3 (folate receptor-positive) and MG-63 (folate receptor-negative) cells were transfected with chitosan-siRNA and folate-chitosanSSB complexes, respectively. The transfection efficiency of polymer-siRNA complexes was analyzed relative to SSB mRNA expression by real-time RT-PCR. HeLa (Figure 6A), OV-3 (Figure 6B), and MG-63 (Figure 6C) cells treated with free SSB siRNA achieved approximately $25 \%$ knockdown of SSB mRNA expression compared with nontreated cells. No change in SSB mRNA expression was evident with $25 \mathrm{kDa}$ chitosan-siRNA compared with nontransfected cells (negative controls) in all three cell lines. However, silencing efficiency was dependent on and increased with the molecular weight of chitosan. $50 \mathrm{kDa}$ chitosan-siRNA nanoparticles exerted a $15 \%$ gene-silencing effect in HeLa cells (Figure 6A), whereas OV-3 cells transfected with $50 \mathrm{kDa}$ chitosan-siRNA nanoparticles generated 53\% gene silencing.
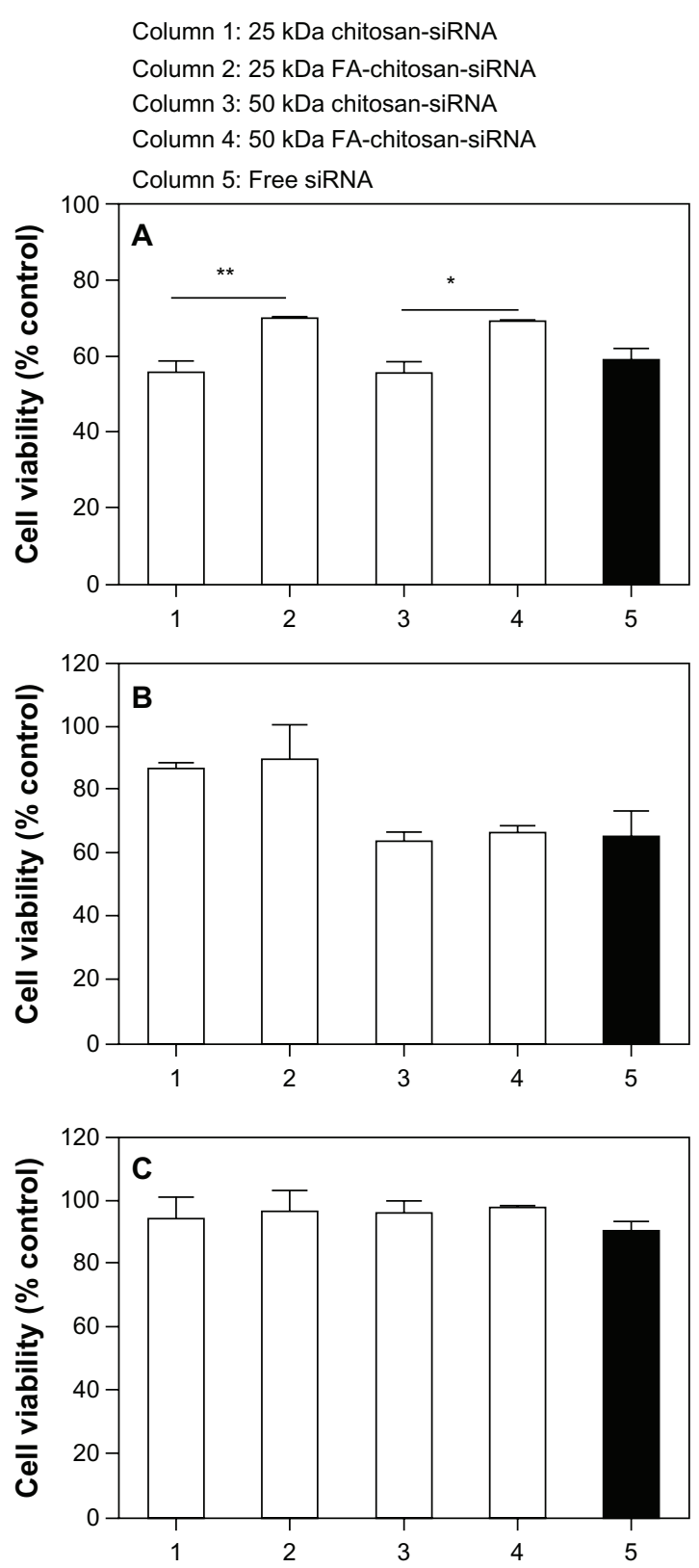

Figure 5 Cell viability. (A) HeLa, (B) OV-3, and (C) MG-63 line cells were transfected with either $5 \mu \mathrm{g}$ free siRNA SSB or with chitosan-siRNA or folate-chitosan-siRNA complexes containing an equivalent of $5 \mu \mathrm{g}$ of siRNA SSB.

Notes: Viability was measured with the MTT assay and compared with nontreated cells, which are considered as $100 \%$. Statistical significance was assessed by unpaired Student's $t$-test, $* P<0.05$; $* * P<0.0$ I. Column I, $25 \mathrm{kDa}$ chitosan-siRNA; column 2, 25 kDa folate-chitosan-siRNA; column 3, 50 kDa chitosan-siRNA; column 4, $50 \mathrm{kDa}$ folate-chitosan-siRNA; column 5 , free siRNA.

Abbreviations: FA, folic acid; SBB, Sjogren syndrome antigen; siRNA, small interfering RNA. 
Column 1: $25 \mathrm{kDa}$ chitosan-siRNA

Column 2: 25 kDa FA-chitosan-siRNA

Column 3: $50 \mathrm{kDa}$ chitosan-siRNA

Column 4: $50 \mathrm{kDa}$ FA-chitosan-siRNA

Column 5: Free siRNA
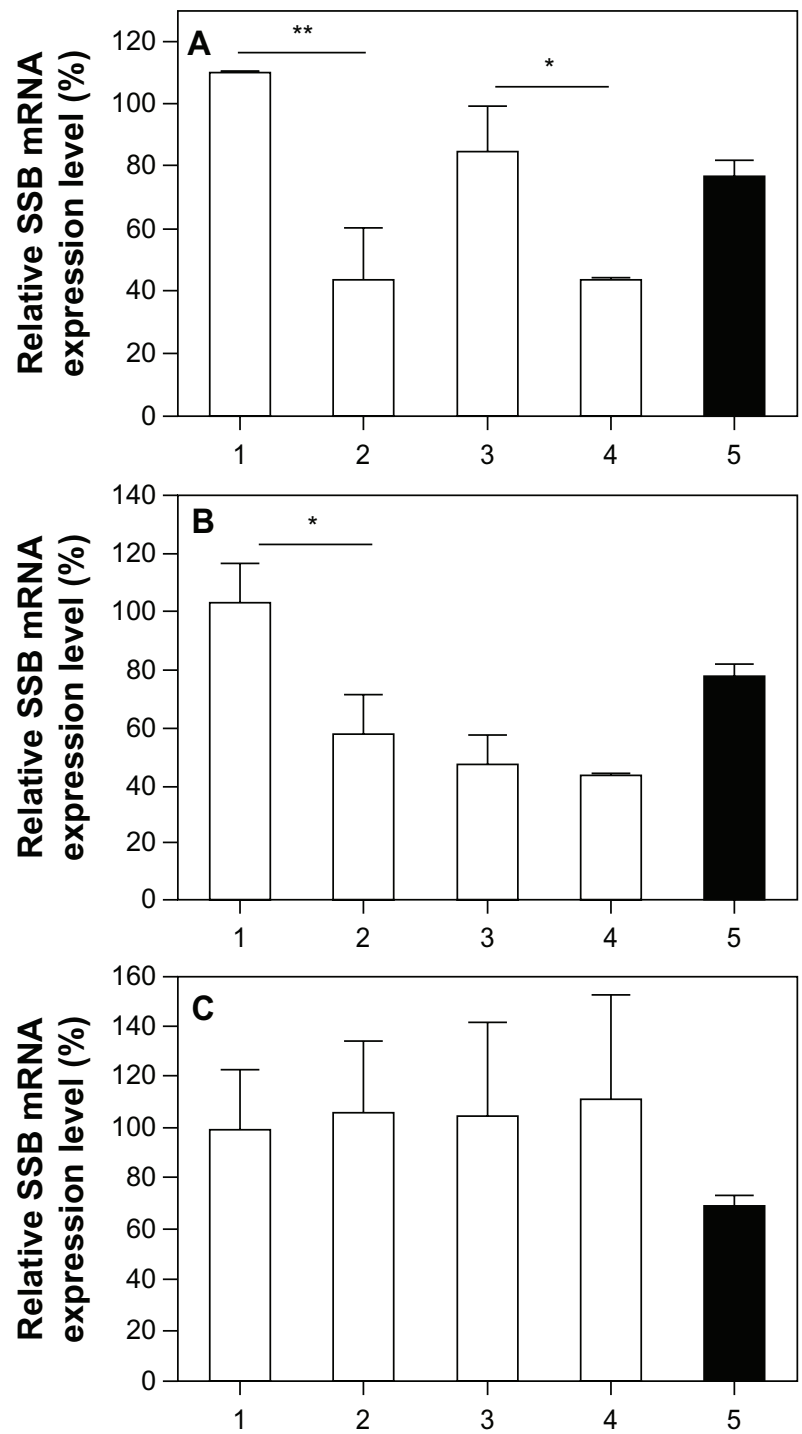

Figure 6 Transfection efficiency in vitro. $5 \mu \mathrm{g}$ free siRNA SSB or chitosan-siRNA or folate-chitosan-siRNA complexes containing an equivalent of $5 \mu \mathrm{g}$ of siRNA SSB incubated with (A) HeLa, (B) OV-3, and (C) MG-63 line cells.

Notes: The weight ratio of chitosan or folate-chitosan to siRNA SSB was 50:I. SSB gene expression is measured with real-time RT-PCR and compared with nontreated cells, which are considered as $100 \%$. Statistical significance was assessed by the unpaired Student's $t$-test, $* P<0.05$; **P $<0.0$ I; $P<0.001$. Column I, $25 \mathrm{kDa}$ chitosan-siRNA; column 2, $25 \mathrm{kDa}$ folate-chitosan-siRNA; column 3, $50 \mathrm{kDa}$ chitosan-siRNA; column 4, 50 kDa folate-chitosan-siRNA; column 5, Free siRNA. Abbreviations: RT-PCR, reverse transcription-polymerase chain reaction; SBB, Sjogren syndrome antigen; siRNA, small interfering RNA.

MG-63 cells displayed no SSB knockdown with $25 \mathrm{kDa}$ or $50 \mathrm{kDa}$ chitosan-siRNA transfection. Folate conjugation improved the gene silencing efficiency of chitosan. HeLa cells transfected with $25 \mathrm{kDa}$ or $50 \mathrm{kDa}$ folate-chitosan-siRNA showed significantly reduced transcription of SSB mRNA
(57\% knockdown of SSB mRNA expression) compared with $25 \mathrm{kDa}(P<0.01)$ and $50 \mathrm{kDa}(P<0.05)$ chitosansiRNA, respectively. Compared with normal nontreated cells, $25 \mathrm{kDa}$ and $50 \mathrm{kDa}$ folate-chitosan-SSB siRNA, respectively, inhibited $42 \%$ and $57 \%$ of SSB gene expression in iOV-3 cells; $25 \mathrm{kDa}$ or $50 \mathrm{kDa}$ folate-chitosan-SSB siRNA manifested no SSB mRNA inhibitory effect in folate receptornegative MG-63 cells. Chitosan-siRNA complexes containing mismatched control siRNA showed no SSB inhibition, confirming gene silencing efficiency (data not included).

\section{Competition analysis of folate-chitosan- siRNA complexes with free FA}

As indicated in Figure 7A, HeLa cells transfected with $25 \mathrm{kDa}$ folate-chitosan-siRNA showed significantly $(P<0.01)$ reduced transcription of SSB mRNA
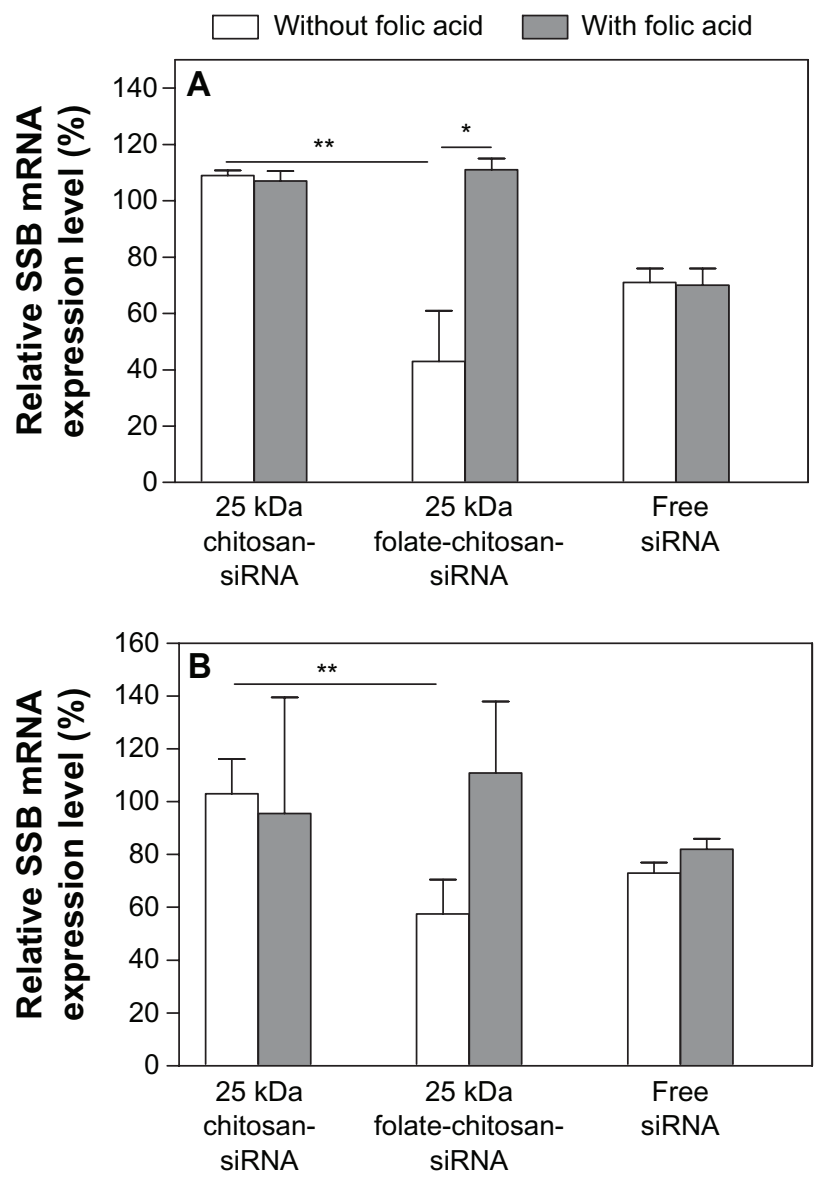

Figure 7 Folic acid competition study. $5 \mu \mathrm{g}$ free siRNA SSB or chitosan-siRNA or folate-chitosan-siRNA complexes containing an equivalent of $5 \mu \mathrm{g}$ of siRNA SSB incubated with (A) HeLa and (B) OV-3 line cells with or without $20 \mu \mathrm{g}$ free folic acid. Notes: SSB gene expression is measured with real-time RT-PCR and compared with nontreated cells, which are considered as $100 \%$. Statistical significance was assessed by the unpaired Student's $t$-test, $* P<0.05$; $* * P<0.01$.

Abbreviations: RT-PCR, reverse transcription-polymerase chain reaction; SBB, Sjogren syndrome antigen; siRNA, small interfering RNA. 
(57\% knockdown of SSB mRNA expression) compared with $25 \mathrm{kDa}$ chitosan-siRNA. In OV-3 cells (Figure 7B), $25 \mathrm{kDa}$ folate-chitosan-SSB siRNA inhibited $42 \%$ of SSB gene expression in comparison with normal nontreated cells. Folate-chitosan-siRNA transfection efficiency decreased in the presence of free FA in these cells, suggesting that free FA molecules prevent cellular uptake of the complexes by competitive binding to folate receptors on cell surfaces.

\section{Discussion}

siRNA silencing technology has been exploited in a wide range of biological studies, but has also become one of the most challenging therapeutic strategies. However, because of its poor delivery and susceptibility to degradation by nuclease, siRNA-based approaches need a protective delivery system. A number of polymer formulations have been proposed in the literature as potential carriers. ${ }^{1-3}$ Polymer molecular weight, charge density, the ratio of protonatable polymer amine groups to nucleic acid phosphate groups, and the ionic strength of the medium can affect electrostatic binding between siRNA and cationic polymers. Research over the years has revealed that chitosan is one of the more desirable polymeric carriers of siRNA because of its natural biocompatibility, biodegradability, nontoxicity, and high nuclease resistance. The effects of different chitosan (114 kDa or more)-siRNA complexes on transfection activity have been investigated previously. ${ }^{6-9}$ Rojanarata et $\mathrm{al}^{7}$ reported that chitosan-thiamine pyrophosphate-mediated siRNA enhanced green fluorescent protein gene silencing efficiency, depending on the molecular weight and weight ratio of chitosan and siRNA. Chitosan-thiamine pyrophosphate-siRNA complexes with the lowest chitosan molecular weight $(20 \mathrm{kDa})$ at a weight ratio of 80 showed the strongest inhibition of gene expression. ${ }^{7}$ The results of our study are in good agreement with reports in the literature.

Complexes prepared from $2 \mathrm{kDa}$ and $5 \mathrm{kDa}$ chitosan were the largest in size and their migration trace for siRNA could be observed. Moreover, $2 \mathrm{kDa}$ or $5 \mathrm{kDa}$ chitosan alone (or chitosan-siRNA complex) showed more toxicity than the other chitosan preparations. The 10,25 , and $50 \mathrm{kDa}$ chitosansiRNA formed nanosized particles ( $\leq 220 \mathrm{~nm}$ ), but only complete binding of siRNA with $25 \mathrm{kDa}$ or $50 \mathrm{kDa}$ chitosan could be seen and showed delayed siRNA migration without the presence of a trailing band. Our results are consistent with those of a previous study which demonstrated a weak interaction between siRNA and chitosan at a very low molecular weight of about $10 \mathrm{kDa} .{ }^{6}$ Higher molecular weight chitosan molecules are long and flexible, but have a higher degree of deacetylation (meaning increased positive charge), which enhances electrostatic interaction with siRNA, thus synergistically reducing the size of the complexes and enhancing their stability. As a favorable nonviral vector involved in the delivery of plasmid DNA, $5 \mathrm{kDa}$ and $10 \mathrm{kDa}$ chitosan can form stable chitosan-DNA nanoparticles (data not included). Differences in complexation between chitosanplasmid DNA and chitosan-siRNA need to be investigated further because of a divergence in size and charge density between plasmid DNA and siRNA.

Taken together, our findings show that binding of siRNA to chitosan was dependent on both the molecular weight of chitosan and the chitosan to siRNA weight ratio. The $25 \mathrm{kDa}$ and $50 \mathrm{kDa}$ chitosan-siRNA nanoparticles formed at a molecular ratio of 50:1 were more stable. We chose $25 \mathrm{kDa}$ and $50 \mathrm{kDa}$ chitosan to synthesize folate-chitosan.

Interestingly, size and particle surface charge were decreased after introduction of the folate ligand onto chitosan. A positive zeta potential of the polymer is necessary to ensure the uptake of complexes by cells carrying a negative charge. It has been reported by our group that the size of folate-chitosan-DNA is indirectly proportional to the charge ratio and zeta potential of folate-chitosan-DNA. ${ }^{22}$ Due to its short length (21-25 base pairs) and linearity, siRNA binds to folate-chitosan in a manner that is different from plasmid DNA. The weak interaction of siRNA with folate-chitosan contributes to the formation of smaller folate-chitosan-siRNA complexes.

Until recently, folate-conjugated nonviral systems with cationic liposomes and polymer were used to condense siRNA to nanoparticles. No study has attempted to illustrate the ability of folate-conjugated chitosan as a siRNA delivery system. Due to its cationic characteristics, chitosan is able to form complexes with negatively-charged DNA or siRNA by electrostatic interaction. In the present work, simple complexation was used to prepare chitosan and folatechitosan-siRNA complexes. Our electrophoresis analysis results show that introduction of the folate ligand did not affect siRNA-binding ability. However, sizes of the folatechitosan-siRNA complexes were decreased in comparison with chitosan-siRNA. As reported by Chan et al, ${ }^{21}$ the water solubility of folate-PEG-chitosan $(255 \mathrm{kDa})$ was slightly lower than that of PEG-chitosan, owing to the introduction of hydrophobic groups in folate, inducing the precipitation of these conjugates.

In general, chitosan and folate-chitosan are nontoxic as nonviral gene delivery vectors in vitro. Folate-chitosanDNA nanoparticles have lower cytotoxicity than commercial 
transfection agents, such as Lipofectamine 2000. ${ }^{22}$ Decreased cytotoxicity has also been reported after grafting folate-PEG onto polyethylenimine (PEI), which is considered to have high cell toxicity. ${ }^{23}$ In this study, average cell viability with $25 \mathrm{kDa}$ or $50 \mathrm{kDa}$ chitosan-siRNA was $54 \%-65 \%$ compared with nontreated cells. It increased slightly when the cells were incubated with folate-chitosan-siRNA. These results are in agreement with our previous study, ${ }^{24}$ which revealed that folate-chitosan-interleukin-1 receptor antagonist plasmid DNA has a better toxicity profile than naked DNA or chitosan-DNA.

The ability of chitosan to deliver DNA and siRNA both in vitro and in vivo has been reported recently. ${ }^{6-10}$ However, data on folate receptor-targeting delivery of cationic polymer folate-PEG-PEI are available. ${ }^{23}$ Folate was conjugated to PEI to increase transfection efficiency for targeting purposes because of its low immunogenicity, low toxicity, and high affinity for folate receptors. Folate-PEG-PEI has been demonstrated to be a potentially safe and efficient gene vector, particularly for folate receptor-positive cell gene delivery. In the present study, we determined that folate-chitosan could be complexed with siRNA, and the results with folate-chitosan-siRNA complexes show folate receptor-specific gene transfection. Surface-exposed folate ligands on the complexes were recognized by folate receptors on the membranes of targeted cancer cells, providing active transport of folate-chitosansiRNA complexes into HeLa and OV-3 cells. We found that folate-conjugated chitosan had greater potential for delivery to targeted cells. The delivery of chitosan complexes to specific cell types has been achieved by conjugating chitosan to various cell-targeted ligands, such as galactose, lactose, and trisaccharides. ${ }^{25}$ Targeting of tumor cells is promoted by conjugating chitosan with folate. ${ }^{13}$ Expression of the folate receptor in synovial mononuclear cells and CD14+ cells in patients with rheumatoid arthritis has been reported. ${ }^{25}$ We have already successfully performed characterization, internalization, and in vitro and in vivo studies of a nonviral gene therapy vector based on chitosan nanoparticles and interleukin-1 receptor antagonist gene therapy in an adjuvantinduced arthritis rat model of rheumatoid arthritis. ${ }^{22,26}$

Free FA competes with folate-chitosan-siRNA complexes for folate receptor-binding. In HeLa cells, as seen in Figure 7, SSB mRNA expression was significantly higher $(P<0.05)$ when transfection was undertaken with $25 \mathrm{kDa}$ folate-chitosan-SSB siRNA complexes in the presence of free FA. Therefore, the transfection ability of HeLa cells was significantly decreased due to free FA in culture medium, whereas no significant difference was found when
MG-63 cells (folate receptor-negative) were transfected in the presence of free FA in medium (data not included). These findings indicate that free FA molecules can prevent cellular uptake of the complexes by competitive binding to folate receptors on the cell surface. Folate conjugation improves the transfection efficiency of folate-chitosan for folate receptor-positive cell gene silencing under normal conditions without excess free FA. Because of folate receptor overexpression and activated macrophages in cancer cells, a number of therapeutic agents have been linked with FA for selective delivery to pathological cells, by avoiding normal tissues. Among these therapies, folate-targeted nonviral vectors are considered to be promising treatments for cancer and inflammatory diseases. ${ }^{13-15}$

In conclusion, siRNA binding to chitosan depends on molecular weight and the chitosan to siRNA weight ratio. Very low molecular weight chitosan $(<10 \mathrm{kDa})$ has difficulty in forming stable complexes with siRNA. Its binding ability is improved when its molecular weight is $25 \mathrm{kDa}$ or more. After addition of a folate ligand to chitosan, the viability and transfection efficiency of folate-chitosan-siRNA complexes in vitro depend on the weight ratios of folate-chitosan to siRNA as well as the type of cell transfected. Higher transfection efficiency and lower toxicity of folate-chitosan are observed in folate receptor-positive (HeLa and OV-3) cells. These findings should encourage further exploration of folate-targeted nonviral gene therapies in cancer and inflammatory diseases, such as arthritis.

\section{Acknowledgments}

This work was supported by grants from the National Natural Science Foundation of China (30811120440 and 30911120261), the Shanghai International Collaboration Foundation (08410701800), the Ministry of Science and Technology of China (No.2011DFA30790) and the Canadian Institutes of Health Research (CCM104888). JCF and MB are research scholars of Fonds de la Recherche en Santé du Québec. The authors thank Merck and Co, Inc, for providing the SSB-targeted siRNA used in this study.

\section{Disclosure}

The authors report no conflicts of interest in this work.

\section{References}

1. Gary DJ, Puri N, Won YY. Polymer-based siRNA delivery: Perspectives on the fundamental and phenomenological distinctions from polymer-based DNA delivery. J Control Release. 2007;121:64-73.

2. Zhang S, Zhao B, Jiang H, Wang B, Ma B. Cationic lipids and polymers mediated vectors for delivery of siRNA. J Control Release. 2007;123:1-10. 
3. De Fougerrolles AR. Delivery vehicles for small interfering RNA in vivo. Hum Gene Ther. 2008;19:125-132.

4. Hammond SM, Bernstein E, Beach D, Hannon GJ. An RNA-directed nuclease mediates post-transcriptional gene silencing in Drosophila cells. Nature. 2000;404:293-296.

5. Chen M, Granger AJ, Vanbrocklin MW, et al. Inhibition of avian leukosis virus replication by vector-based RNA interference. Virology. 2007;365:464-472.

6. Liu X, Howard KA, Dong M, et al. The influence of polymeric properties on chitosan/siRNA nanoparticle formulation and gene silencing. Biomaterials. 2007;28:1280-1288.

7. Rojanarata T, Opanasopit P, Techaarpornkul S, Ngawhirunpat T, Ruktanonchai U. Chitosan-thiamine pyrophosphate as a novel carrier for siRNA delivery. Pharm Res. 2008;25:2807-2814.

8. Katas H, Alpar HO. Development and characterisation of chitosan nanoparticles for siRNA delivery. J Control Release. 2006;115: 216-225.

9. Katas H, Chen S, Osamuyimen AA, Cevher E, Alpar HO Effect of preparative variables on small interfering RNA loaded poly(D,L-lactide-co-glycolide)-chitosan submicron particles prepared by emulsification diffusion method. J Microencapsul. 2008;25:541-548.

10. Howard KA, Rahbek UL, Liu X, et al. RNA interference in vitro and in vivo using a novel chitosan/siRNA nanoparticle system. Mol Ther. 2006; 14:476-484.

11. Godbey WT, Wu KK, Mikos AG. Size matters: molecular weight affects the efficiency of poly(ethylenimine) as a gene delivery vehicle. J Biomed Mater Res A. 1999;45:268-275.

12. Lavertu M, Methot S, Tran-Khanh N, Buschmann MD. High efficiency gene transfer using chitosan/DNA nanoparticles with specific combinations of molecular weight and degree of deacetylation. Biomaterials. 2006;27:4815-4824.

13. Sudimack J, Lee RJ. Targeted drug delivery via the folate receptor. $A d v$ Drug Deliv Rev. 2000;41:147-162.

14. Low PS, Antony AC. Folate receptor-targeted drugs for cancer and inflammatory diseases. Adv Drug Deliv Rev. 2004;56:1055-1058.

15. Lee D, Lockey R, Mohapatra S. Folate receptor-mediated cancer cell specific gene delivery using folic acid-conjugated oligochitosans. J Nanosci Nanotechnol. 2006;6:2860-2866.
16. Allan GG, Peyron M. Molecular weight manipulation of chitosan II prediction and control of extent of depolymerization by nitrous acid. Carbohydr Res. 1995;277:273-282.

17. Mima S, Miya M, Iwamoto R, Yoshikawa S. Highly deacetylated chitosan and its properties. J Appl Polym Sci. 1983;28:1909-1917.

18. Cho KC, Jeong JH, Chung HJ, Joe CO, Kim SW, Park TG. Folate receptor-mediated intracellular delivery of recombinant caspase-3 for inducing apoptosis. J Control Release. 2005;108:121-131.

19. Bolstad AI, Eiken HG, Rosenlund B, Alarcón-Riquelme ME, Jonsson R. Increased salivary gland tissue expression of Fas, Fas ligand, cytotoxic $\mathrm{T}$ lymphocyte-associated antigen 4, and programmed cell death 1 in primary Sjögren's syndrome. Arthritis Rheum. 2003;48:174-185.

20. Kreuzer KA, Lass U, Landt O, et al. Highly sensitive and specific fluorescence reverse transcription-PCR assay for the pseudogene-free detection of beta-actin transcripts as quantitative reference. Clin Chem. 1999;45:297-300.

21. Chan P, Kurisawa M, Chung JE, Yang YY. Synthesis and characterization of chitosan-g-poly(ethylene glycol)-folate as a non-viral carrier for tumor-targeted gene delivery. Biomaterials. 2007;28:540-549.

22. Mansouri S, Cuie Y, Winnik F, et al. Characterization of folate-chitosan-DNA nanoparticles for gene therapy. Biomaterials. 2006;27:2060-2065.

23. Kim SH, Jeong JH, Cho KC, Kim SW, Park TG. Target-specific gene silencing by siRNA plasmid DNA complexed with folate-modified poly(ethylenimine). J Control Release. 2005;104:223-232.

24. Mintzer MA, Simanek EE. Nonviral vectors for gene delivery. Chem Rev. 2009;109:259-302.

25. Nakashima-Matsushita N, Homma T, Yu S, et al. Selective expression of folate receptor beta and its possible role in methotrexate transport in synovial macrophages from patients with rheumatoid arthritis. Arthritis Rheum. 1999;42:1609-1616.

26. Fernandes JC, Wang H, Jreyssaty C, et al. Bone-protective effects of nonviral gene therapy with folate-chitosan DNA nanoparticle containing interleukin-1 receptor antagonist gene in rats with adjuvant-induced arthritis. Mol Ther. 2008;16:1243-1251. 


\section{Supplementary information Synthesis of low molecular weight chitosans}

Chitosans of lower molecular weight $(2,5,10$, and $25 \mathrm{kDa})$ was prepared by nitrous acid degradation. Briefly, the procedure is explained here for the synthesis of chitosan $25 \mathrm{kDa}$. Chitosan (molecular weight $53 \mathrm{kDa}, 5.0 \mathrm{~g}$ ) was dissolved in $500 \mathrm{~mL}$ of $2 \%$ acetic acid solution. Sodium nitrite $\left(\mathrm{NaNO}_{2}, 35 \mathrm{mg}, 0.5 \mathrm{mmol}\right)$ in $10 \mathrm{~mL}$ of doubledistilled water was added in four aliquots. The reaction was conducted at $40^{\circ} \mathrm{C}-50^{\circ} \mathrm{C}$ for $5-6$ hours. After that, the $\mathrm{pH}$ of the chitosan solution was adjusted to $>10$ by adding $\mathrm{NaOH}$ solution $(5 \mathrm{M})$. The white precipitate generated was collected by filtration and washed with double-distilled water until the filtrate became neutral (yield $3.3 \mathrm{~g}, 66 \%$ ).

The molecular weight of chitosan was determined by gel permeation chromatography with multiple angle light scattering detection. Gel permeation chromatography analyses were carried out on a gel permeation chromatography system consisting of an Agilent 1100 isocratic pump, a Dawn EOS multiangle laser light scattering detector (Wyatt Technology Corporation, Santa Barbara, CA), an Optilab DSP interferometric refractometer (Wyatt Technology), and a TSK-GELPW (Tosoh Biosep, King of Prussia, PA) column eluted with a $\mathrm{pH} 4.5$ acetic acid $(0.3 \mathrm{M})$ /sodium acetate $(0.2 \mathrm{M})$ buffer, injection volume $100 \mathrm{ul}$, flow rate $0.5 \mathrm{~mL}$ per minute, temperature $25.0^{\circ} \mathrm{C}$. The $\mathrm{dn} / \mathrm{dc}$ values of the polymers were measured at $690 \mathrm{~nm}$ with the same refractometer used in the off-line mode. Characterizations of the chitosans are listed in Table S1.

\section{Synthesis of chitosan-PEG-folate conjugate}

Two chitosans, ie, chitosan $50 \mathrm{~K}$ and chitosan $25 \mathrm{~K}$ were selectively modified with folate via a PEG $3.4 \mathrm{~K}$ spacer.

Table SI Characterization of the chitosans

\begin{tabular}{lll}
\hline Sample & MW (kDa) & MW \\
\hline Chitosan 2 K & 2.4 & 1.2 \\
Chitosan 5 K & 5.5 & 1.2 \\
Chitosan 10 K & 10.8 & 1.3 \\
Chitosan 25 K & 25.4 & 1.6 \\
Chitosan 50 K & 53.4 & 1.5 \\
\hline
\end{tabular}

Abbreviations: $\mathrm{Mw}$, weight average molecular weight; $\mathrm{Mn}$, number average molecular weight.
The synthesis scheme for chitosan-PEG-folate conjugate is shown in Scheme S1. The conjugate was prepared according to the synthetic procedure reported by Cho et a ${ }^{18}$ with slight modification. The synthesis was accomplished in three steps, as follows.

- Folate-NHS-ester: folic acid (300 mg, $0.67 \mathrm{mmol})$ was dissolved in $12 \mathrm{~mL}$ of dry dimethylsulfoxide to which $93 \mathrm{mg}(0.45 \mathrm{mmol})$ of dicyclohexylcarbodiimide (DCC) and $77 \mathrm{mg}(0.67 \mathrm{mmol})$ of N-hydroxysuccinimide (NHS) were added. The mixture was stirred at room temperature for 6 hours. The white precipitate (a side product of the reaction) was removed by filtration. The filtrate was added to $100 \mathrm{~mL}$ of $30 \%$ acetone in diethyl ether. The resulting yellow precipitate (folate-NHS-ester) was collected by filtration and washed with acetone and ether. It was used immediately in the next step of synthesis. The yield was $250 \mathrm{mg}(83 \%)$.

- Folate-PEG-COOH: $\mathrm{NH}_{2}-\mathrm{PEG}-\mathrm{COOH}(450 \mathrm{mg}, 0.13 \mathrm{mmol}$, molecular weight $3400 \mathrm{Da}$, Shearwater Polymers, Huntsville, AL) was dissolved in $100 \mathrm{~mL}$ of dry pyridine. The folate-NHS-ester (approximately $250 \mathrm{mg}, 0.55 \mathrm{mmol}$ ) was added to the solution and the reaction mixture was stirred overnight in the dark. Upon completion of the reaction, the pyridine was evaporated in vacuo and the remaining solid was dissolved in $20 \mathrm{~mL}$ of deionized water. The product was purified by dialysis against $\mathrm{pH} 7.4$ phosphate buffer $(10 \mathrm{mM})$ for one day and against deionized water for two days. The yield was $450 \mathrm{mg}$ (76\%).

- Chitosan-PEG-folate: Chitosan (200 mg, $1.0 \mathrm{mmol}$ amino groups) was dissolved in $20 \mathrm{~mL}$ of $2 \%$ acetic acid aqueous solution. To this solution, folate-PEG-COOH $(40 \mathrm{mg}$, $10 \mu \mathrm{mol}$ in $5 \mathrm{~mL}$ of dimethylsulfoxide and preactivated by reacting with [3-(-dimethylamino)propyl]carbodiimide (EDC, $2.5 \mathrm{mg}, 15 \mu \mathrm{mol})$ and NHS $(5.8 \mathrm{mg}, 25 \mu \mathrm{mol})$ for 4 hours) was added dropwise. The reaction was continued in the dark for 20 hours with constant stirring. The reaction mixture was then dialyzed using a membrane (molecular weight cutoff, 12-14 kDa) against deionized water for 3 days. The chitosan-PEG-folate conjugate was recovered by freeze-drying. The yield was $210 \mathrm{mg}$.

The structure of chitosan-PEG-folate conjugate is illustrated in Figure S1. 
<smiles>Nc1nc2ncc(CNc3ccc(C(=O)NC(CCC(=O)O)C(=O)O)cc3)nc2c(=O)[nH]1</smiles>

$$
\underset{\mathrm{NH}_{2}\left(\mathrm{CH}_{2} \mathrm{CH}_{2} \mathrm{O}\right) \mathrm{nCH}_{2} \mathrm{COOH}}{\longrightarrow}
$$<smiles>Cc1nc2ncc(CNc3ccc(C(=O)NC(CCC(=O)NCCOCC(=O)O)C(=O)O)cc3)nc2c(=O)[nH]1</smiles>

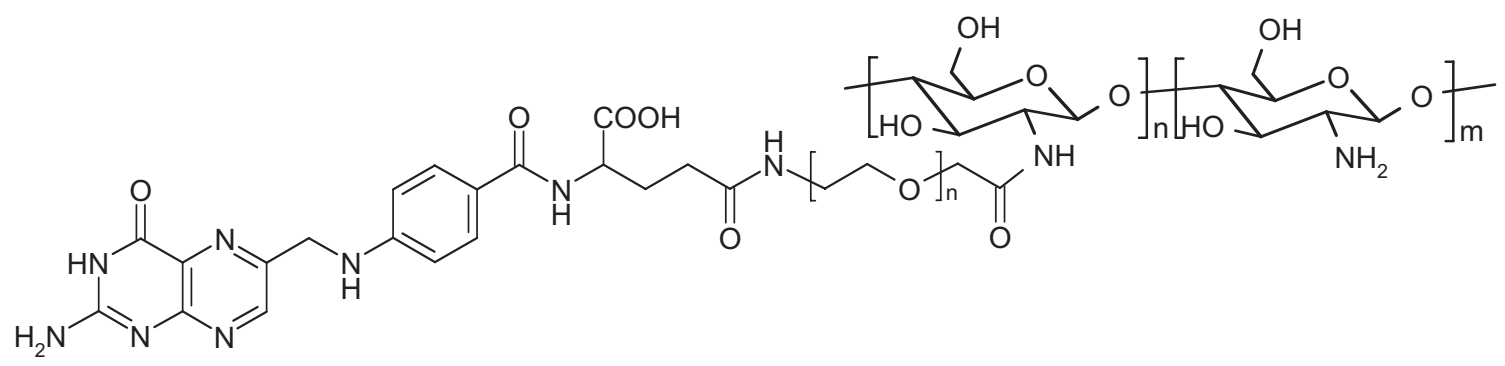

Scheme SI Synthetic procedure of folate-PEG-chitosan.

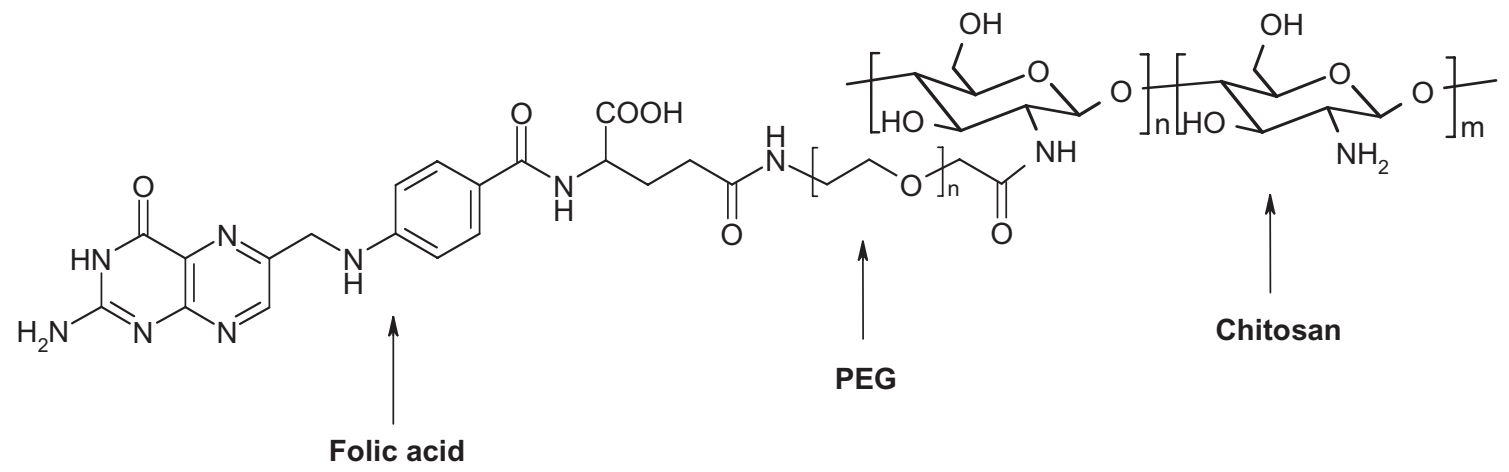

Figure SI Structure of chitosan-PEG-folate conjugate.

\section{Publish your work in this journal}

The International Journal of Nanomedicine is an international, peerreviewed journal focusing on the application of nanotechnology in diagnostics, therapeutics, and drug delivery systems throughou the biomedical field. This journal is indexed on PubMed Central,

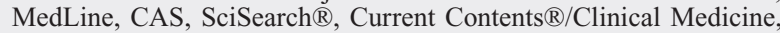

Journal Citation Reports/Science Edition, EMBase, Scopus and the Elsevier Bibliographic databases. The manuscript management system is completely online and includes a very quick and fair peer-review system, which is all easy to use. Visit http://www.dovepress.com/ testimonials.php to read real quotes from published authors. 